\title{
INVENTARISASI KEBERADAAN DAN PENYEBARAN JEJAK MACAN TUTUL (Panthera pardus melas Curvier, 1809) DI HUTAN LINDUNG CIJAMBU KABUPATEN SUMEDANG)
}

\author{
Inventory of Existence and Distribution Leopard Footprint \\ (Panthera pardus melas Curvier, 1809) at Cijambu Protected Forest, \\ Sumedang Regency
}

Reni Srimulyaningsih; Egi Prayoga

Universitas Winaya Mukti, Jl. Raya Sumedang Km 29 Tanjungsari-Sumedang 45362; fahutan@unwim.ac.id

\section{Diterima 4 Februari 2018 /Disetujui 18 Februari 2018}

\begin{abstract}
Leopard (Panthera pardus melas Curvier, 1809) is an endangered species that have been protected because of the population decreased and some population extinct locally. One of them is leopard in Protected Forest Cijambu that no has data about leopard of existence. The objective of this research was to inventory leopard existence and to know distribution of leopard in Cijambu Protected Forest. The method of research is Local community interview and identify of leopard footprint by observation and spatial analysis. The research showed that leopard existence by footprint, feces, scratches, and sound. So, estimate individu of leopard in Cijambu Protected Forest is 3 individual, with a footprint the size of front and rear at 1 individual is $7.5 \mathrm{~cm}$ and $7-7.1 \mathrm{~cm}, 1$ individu is $11 \mathrm{~cm}$ and $10.2-10.3 \mathrm{~cm}$, and 1 individual is $6.5 \mathrm{~cm}$ and $5.0 \mathrm{~cm}$. Distribution of footprints leopards in Protected Forests Cijambu is exist in Block Legok honje, Pasir panjang, Gunung putri, Gunung sanggara, Bewak and Pangauban.
\end{abstract}

Keyword: Leopard, inventory, existence, distribution, footprints, cijambu 


\section{PENDAHULUAN}

Sebaran populasi macan tutul saat ini diperkirakan mengalami penurunan sehingga status kelangkaannya dalam Redlist IUCN (International Union for Conservation of Nature and Natural Resources) dari tahun ke tahun meningkat dari Vulnerable (1986), Near Threatened (1988-1990), Lower Risk/ Least Concern (1996), Least Concern (2002), dan pada tahun 2008 dimasukkan ke dalam kategori Critically Endangered (IUCN, 2008). Macan tutul dalam CITES (Conventional on International Trade in Endangered Species of Wild Fauna and Flora) tahun 2016 juga telah dikategorikan ke dalam Appendix I, yang artinya tidak boleh diperdagangkan. Kondisi macan tutul yang demikian memasukkan satwa ini ke dalam salah satu jenis satwa yang dilindungi oleh PP. No.7 tahun 1999 tentang pengawetan jenis tumbuhan dan satwa.

Macan tutul dalam rantai makanan di Pulau Jawa saat ini telah menduduki salah satu top predator dan merupakan spesies kunci (keystone species) dalam ekosistem hutan di Pulau Jawa. Hal ini dikarenakan telah punahnya salah satu top predator Pulau Jawa, yaitu harimau jawa (Panthera tigris sondaica) yang kepunahannya dinyatakan oleh IUCN.

Habitat macan tutul di Jawa Barat terdapat di beberapa kawasan konservasi baik Taman Nasional Cagar Alam, Suaka Margasatwa maupun Taman Buru dan Hutan Lindung. Kawasan tersebut antara lain (Ario, 2010) : Taman Nasional Gunung Gede Pangrango, sebagian Taman Nasional Halimun Salak, Taman Nasional Gunung Ceremai, Cagar Alam Gunung Simpang, Cagar Alam Gunung Tilu, Cagar Alam Gunung Tangkuban Parahu, Cagar Alam Gunung Burangrang, Cagar Alam Kawah Kamojang, Suaka Margasatwa Gunung Sawal, Suaka Margasatwa Cikepuh, Taman Buru Masigit Kareumbi, Hutan Lindung Gunung Masigit, Hutan Lindung Gunung Malabar, Hutan Lindung Gunung Wayang Windu, dan Hutan Lindung Gunung Limbung.

Salah satu habitat macan tutul di Jawa Barat yang diduga sebagai habitat macan tutul, akan tetapi tidak memiliki data mengenai keberadaannya adalah Hutan Lindung Cijambu (HLC). Keberadaan macan tutul ini diperoleh berdasarkan hasil wawancara dengan petugas hutan lindung tersebut yang menyebutkan bahwa terdapat bahwa ciri - ciri keberadaannya berupa jejak kaki (tapak), cakaran, dan kotoran.

Komponen habitat, seperti ketersediaan pakan, air, dan pelindung (cover) yang ada di HLC sangat mendukung bagi keberlangsungan hidup macan tutul. Hal ini terlihat dari hasil wawancara dengan petugas terdapat bebrapa satwa yang biasa dijadikan mangsa/pakan macan tutul tersebut antara lain babi hutan (Sus verrucosus), monyet ekor panjang (Macaca fascicularis), lutung (Trachypithecus 
auratus), kijang (Muntiacus muntjak), bajing (Callosciurus notatus), musang (Paradoxurus hermaphroditus), elang (Spilornis cheela), dan julang (Aceros $s p$ ).

Noviana (2015) juga menambahkan bahwa vegetasi atau tegakan pohon yang menjadi tempat berlindung macan tutul diantaranya adalah saninten (Castanopsis argentea), puspa (Schima walichii), kisireum (Syzigium corymbifera), mindi (Mellia azadarach), bingbin (Pinanga coronate), kitamiang (Trema amboinensis), huru sereh (Laura diversifolia), kileho (Saurauia bracteosa), nangsi (Villebrunea rubescens), kihujan (Samanea saman), kijambe (Areca catechu), lemo (Litsea cubeba), dan jamuju (Dacrycarpus imbricatus).

Kondisi keberadaan macan tutul di HLC yang demikian, diperlukan dengan segera mengenai data inventarisasi jejak untuk memonitoring keberadaannya, sehingga informasi mengenai populasi macan tutul di kawasan ini dapat dijadikan sebagai rekomendasi pengelolaannya. Melihat kondisi tersebut, maka perlu dilakukan penelitian mengenai inventarisasi jejak dan penyebaran macan tutul di HLC sebagai dasar untuk melakukan pengelolaan macan tutul lebih lanjut.

\section{METODE PENELITIAN}

Penelitian dilaksanakan pada bulan Juli sampai Agustus 2016 yang berlokasi di Hutan Lindung Cijambu, RPH Cijambu, BKPH Manglayang Timur, KPH Sumedang, Perusahaan Umum PERHUTANI Divisi Regional Jawa Barat dan Banten (Gambar 1). Peralatan yang digunakan dalam penelitian ini antara lain talley sheet, kuisioner, global position system (GPS), peta kerja, kompas, kamera, meteran, gips, alat tulis, dan komputer dengan software Arc.gis 10.3 dari Esri. Bahan atau objek penelitian ini yaitu macan tutul (Panthera pardus melas Curvier, 1809), dan masyarakat sekitar hutan.

Metode pengumpulan data dilakukan dengan beberapa cara dan tahapan. Tahap pertama, inventarisasi keberadaan macan tutul dilakukan dengan wawancara dan pengamatan tidak langsung. Wawancara yang dilakukan adalah wawancara terstruktur, yaitu dengan menggunakan kuisioner sebagai panduan wawancara untuk menggali informasi mengenai lokasi keberadaan macan tutul menurut masyarakat sekitar hutan HLC. Jumlah sampel (responden) yang diwawancarai adalah 10 orang. Penentuan responden tersebut dengan menggunakan metode Snowball Sampling (Sugiyono, 2008). Responden yang dipilih adalah masyarakat yang sering memasuki (lebih dari 4 kali dalam setahun) dan sudah mengetahui lebih dalam kawasan HLC, dimana tujuan responden memasuki HLC adalah berburu (4 orang), mencari kayu bakar (2 orang), dan mencari jamur (4 orang). 
Pengamatan tidak langsung dilakukan dengan metode transek dengan panjang 1000 meter dan lebar 0,5-2 meter (Santoso, 2014). Waktu pengambilan data dilaksanakan dengan 2 kali ulangan, pada waktu pagi hari dan sore hari. Hal tersebut dilakukan karena menurut Goudriaan (1948) dalam Hoogerwerf (1970), waktu aktif macan tutul mengadakan perburuan adalah antara pukul 15.00 sampai 20.00 dan antara pukul 03.00 sampai 06.00, jadi tidak selalu dalam keadaan gelap. Jumlah transek pengamatan yang digunakan adalah sebanyak 6 transek yang ditempatkan di lokasi yang diduga terdapat jejak macan tutul berdasarkan data wawancara dan survey pendahuluan (Gambar 1). Transek pengamatan berada di lokasi - lokasi yang terbuka atau jalur yang biasa dilalui oleh satwa dan manusia karena macan tutul lebih sering melewati jalur yang terbuka (Gunawan, 1988 dan Gunawan, 2010).

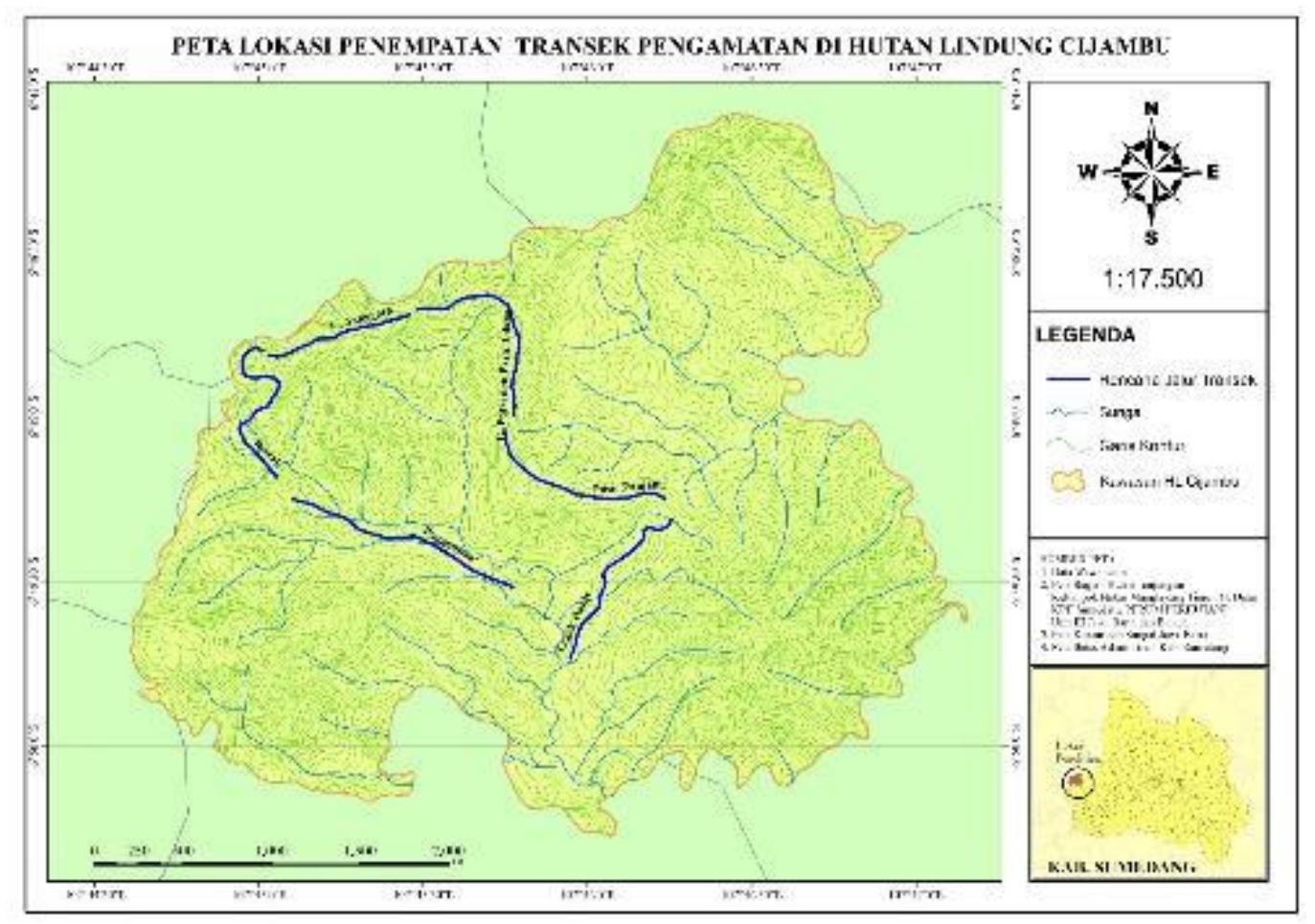

Gambar 1. Peta lokasi penempatan transek pengamatan 
Tahap kedua, pengambilan jejak kaki macan tutul dengan persyaratan sebagai berikut: 1) Jejak kaki masih terlihat jelas, biasanya usia maksimal adalah 3 hari (petugas ahli jejak); dan 2) Tekstur tanah relatif kuat sehingga jejak kaki tidak mudah hancur.

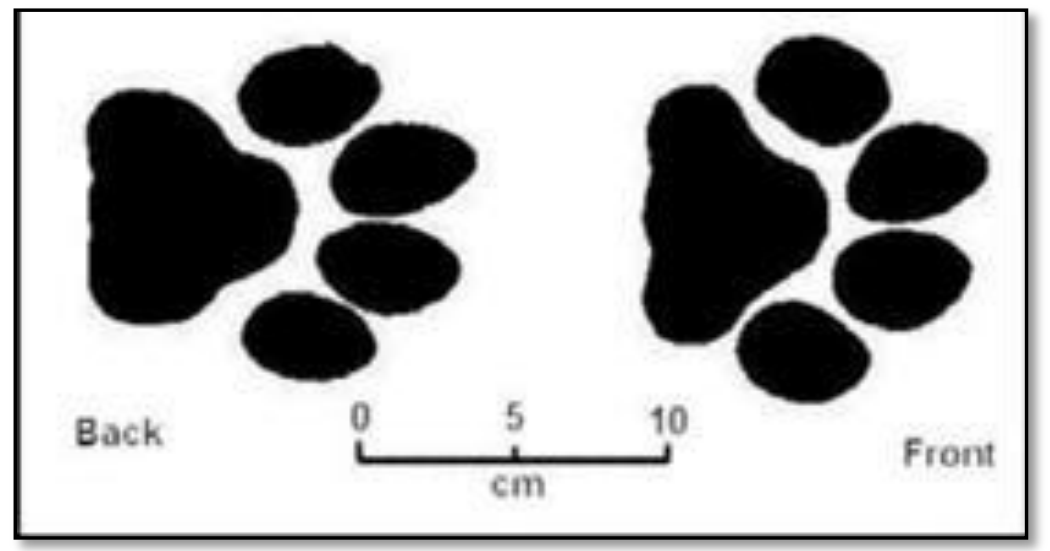

Gambar 2. Bentuk jejak kaki macan tutul (Van Strien (1983))

Tahap ketiga, data penyebaran dilakukan dengan mencatat titik koordinat pada lokasi ditemukannya jejak harimau dengan menggunakan GPS. Pencatatan titik koordinat juga ditandai dengan frekuensi pertemuan jejak.

Analisis data mengenai keberadaan macan tutul dilakukan secara deskriptif dengan mempertimbangkan faktor komponen habitat dan daya dukung lainnya. Jumlah individu macan tutul dilakukan dengan identifikasi ukuran jejak kaki yang ditemukan dengan tahapan sebagai berikut : 1) Pengukuran jejak kaki depan dan belakang macan tutul; 2) Pengelompokan jejak kaki macan tutul berdasarkan ukurannya; dan 3) Memperkirakan jumlah individu macan tutul yang ditemukan dengan asumsi setiap individu memiliki ukuran jejak kaki yang berbeda. Data penyebaran jejak macan tutul dianalisis menggunakan analisis spasial berdasarkan data koordinat jejak kaki yang ditemukan. Data tersebut dikaitkan dengan daya dukung (habitat) yang ada disekitarnya. Data hasil analisis disajikan secara tabulasi dan penyajian peta tentang penyebaran jejak macan tutul di HLC.

\section{HASIL DAN PEMBAHASAN}

\section{Keberadaan Macan Tutul di Hutan Lindung Cijambu}

Jejak keberadaan macan tutul di HLC berdasarkan hasil wawancara terdapat beberapa jejak, seperti jejak kaki, cakaran, bekas pakan, kotoran, dan suara bahkan ada yang pernah melihat secara langsung (11\%) (Gambar 3). Jejak macan 
paling banyak ditemukan oleh masyarakat adalah jejak kaki (36\%), sedangkan paling jarang ditemukan/didengar adalah suara (3\%). Hal ini membuktikan bahwa Macan tutul di HLC masih ada dan masih mudah untuk ditemui. Hal ini diperjelas oleh Cat Specialist Group (2015) yang menyatakan bahwa macan tutul merupakan spesies yang sangat mudah beradaptasi. Mereka ditemukan disetiap tipe hutan, savana, padang rumput, semak, setengah gurun, hutan hujan tropis berawa, pegunungan yang terjal, hutan gugur yang kering, hutan konifer sampai sekitar pemukiman.

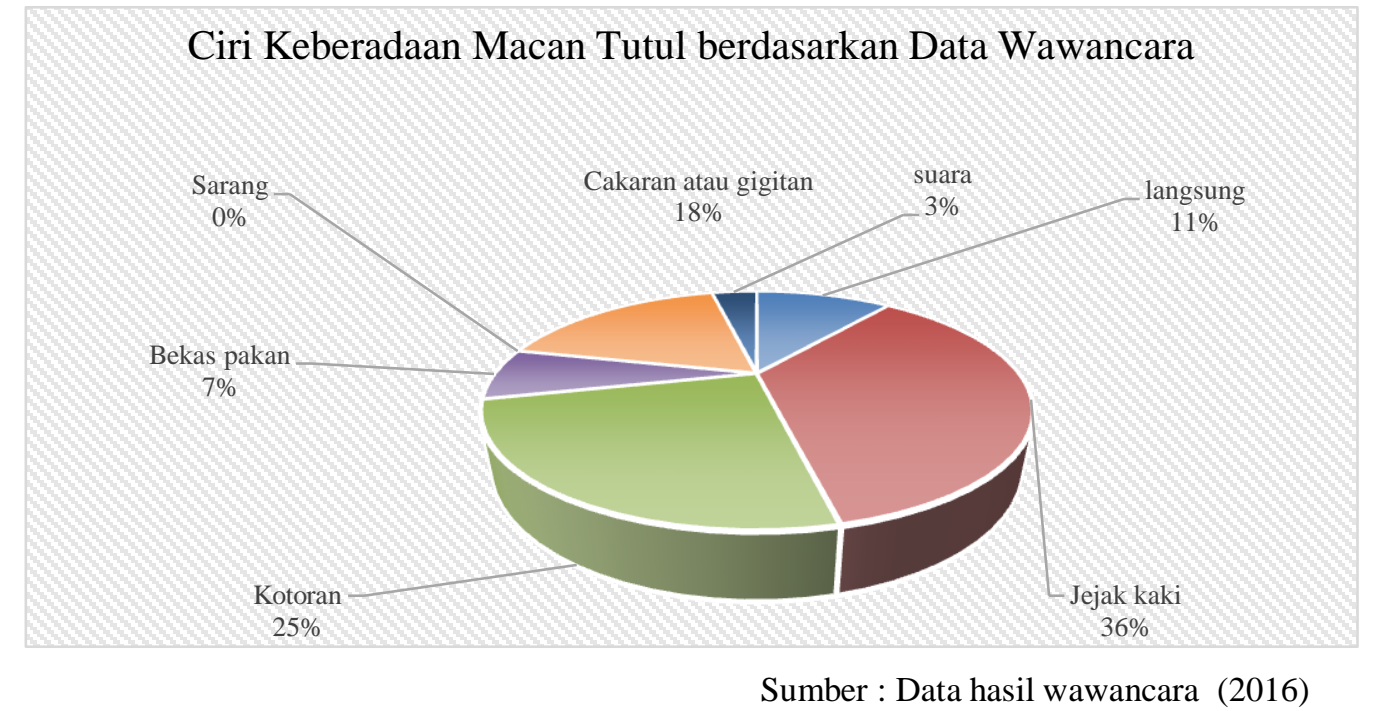

Gambar 3. Ciri keberadaan macan tutul berdasarkan data wawancara

\section{Estimasi Jumlah Individu Macan Tutul di Hutan Lindung Cijambu}

Jumlah individu macan tutul di HLC dari jejak kaki yang ditemukan di 5 titik pada 4 lokasi survei yang berbeda. Ukuran jejak dari ke lima titik jejak tersebut terdapat jejak kaki yang sama, sehingga dapat disimpulkan terdapat jejak kaki dengan individu yang sama. 
Tabel 1. Estimasi jumlah individu macan tutul di Hutan Lindung Cijambu

\begin{tabular}{|c|c|c|c|c|c|}
\hline \multirow[t]{2}{*}{ No } & Uku & $\begin{array}{l}\text { jak Kaki } \\
\text { n) }\end{array}$ & \multirow[b]{2}{*}{$\begin{array}{l}\text { Lokasi } \\
\text { (Blok) }\end{array}$} & \multirow[b]{2}{*}{$\begin{array}{c}\text { Arah } \\
\text { Pergerakan } \\
\text { (Azimut) }\end{array}$} & \multirow[b]{2}{*}{$\begin{array}{c}\text { Jumlah } \\
\text { Individu }\end{array}$} \\
\hline & $\begin{array}{l}1 \\
\vdots \\
1 \\
1 \\
1\end{array}$ & Belakang & & & \\
\hline 1 & 7.5 & 7 & Legok Honje & $290^{\circ}$ & \multirow{2}{*}{1} \\
\hline 2 & 7.5 & 7.1 & Pasir Panjang & $130^{\circ}$ & \\
\hline 3 & 11 & 10.2 & G. Sanggara & $120^{\circ}$ & \multirow{2}{*}{2} \\
\hline 4 & 11 & 10.3 & G. Sanggara & $280^{\circ}$ & \\
\hline 5 & 6.5 & 5 & Pangauban & $320^{\circ}$ & 3 \\
\hline
\end{tabular}

Analisis jejak kaki dari Tabel 1 menunjukan bahwa jumlah macan tutul yang ditemukan sebanyak 3 individu. Hal ini dikarenakan terdapat 2 jejak yang dianggap sama, yaitu jejak di titik 2 dan 3, sehingga dihitung 1 individu. Informasi mengenai temuan jejak kaki macan tutul adalah sebagai berikut :

1. Individu macan tutul yang pertama memiliki ukuran jejak kaki depan $7.5 \mathrm{~cm}$ dan belakang antara 7 - 7,1 cm. Individu ini berada di Blok Legok honje dan Pasir panjang. Arah pergerakan individu ini terdapat 2 arah yang saling berlawanan dalam satu transek pengamatan yaitu $290^{\circ}$ dan $130^{\circ}$. Hal ini menunjukkan bahwa jejak tersebut dapat dihitung menjadi 1 individu.

2. Individu macan tutul yang kedua memiliki ukuran jejak kaki depan $11 \mathrm{~cm}$ dan belakang 10,2 - 10,3 cm. Jika dilihat dari ukuran jejaknya individu ini tergolong cukup dewasa. Individu ini berada di Blok Gunung Sanggara dengan arah pergerakan menuju 2 arah yaitu $120^{\circ}$ dan $280^{\circ}$.

3. Individu macan tutul yang ketiga memiliki ukuran jejak kaki depan $6,5 \mathrm{~cm}$ dan belakang $5 \mathrm{~cm}$. Lokasi jejak kakinya berada di Blok Pangauban dengan arah pergerakan $320^{\circ}$.

Jejak kaki macan tutul di HLC ini hampir sama dengan jejak kaki macan tutul di Cagar Alam Kamojang, Kabupaten Garut seperti halnya hasil penelitian Kurniawan (2009) yang menyebutkan bahwa jejak kaki macan tutul di lokasi penelitiannya antara lain berukuran : a) kaki depan 7,5 cm; b) kaki depan $10 \mathrm{~cm}$, kaki belakang $9 \mathrm{~cm}$; c) kaki depan $8 \mathrm{~cm}$, kaki belakang $5 \mathrm{~cm}$. 

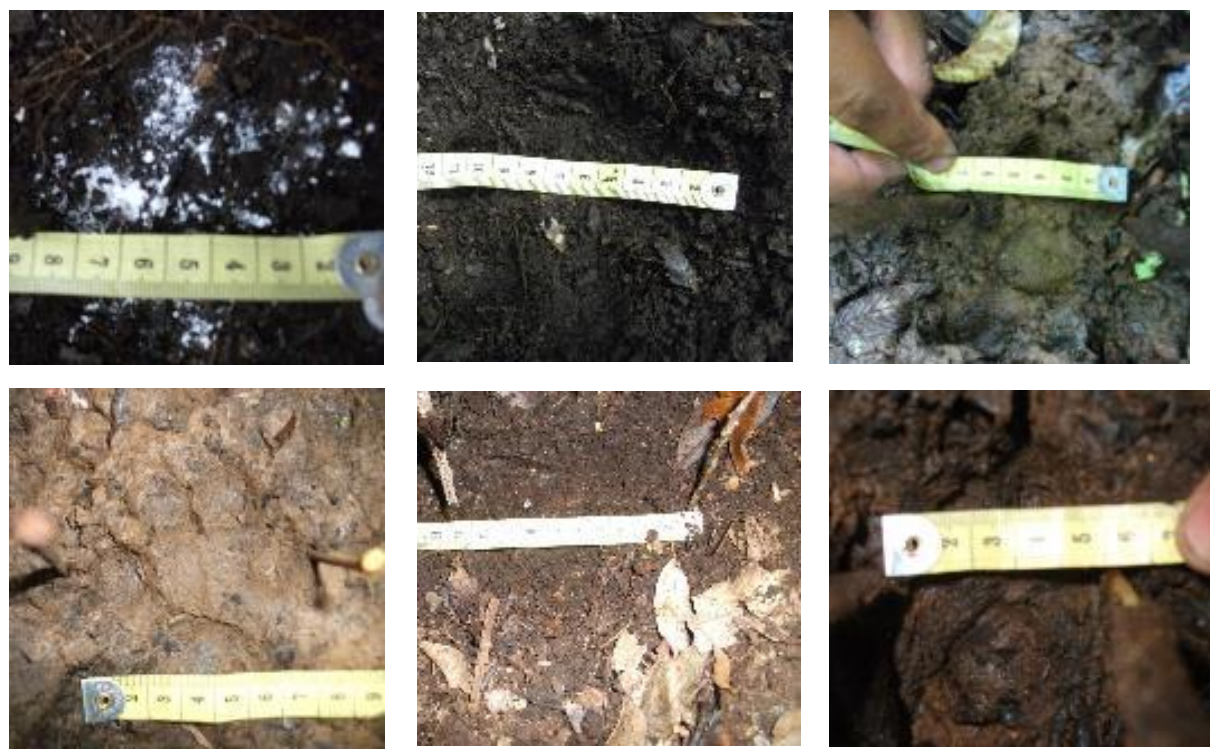

Sumber : Data Pengamatan Lapangan (2016)

Gambar 4. Dokumentasi pengukuran jejak kaki macan tutul (Bagian atas: pengukuran jejak kaki depan, Bagian bawah: pengukuran jejak kaki belakang).

Jumlah individu macan tutul berdasarkan wawancara sekitar 4-6 ekor (51\%) dan yang menyebutkan 2 ekor (16\%). Data tersebut berbeda dengan data pengamatan lapangan yang dilakukan dalam penelitian ini karena masyarakat hanya melihat dari jumlah yang ditemukan oleh mereka, tanpa ada analisis terlebish dahulu. Selain itu aktivitas masyarakat hanya memasuki sebagian kawasan HLC tanpa melihat dari keseluruhan kawasan. Data wawancara terkait jumlah individu macan tutul di HLC disajikan pada Gambar 7.

\section{Penyebaran Jejak Macan Tutul di Hutan Lindung Cijambu}

Macan tutul pada umumnya bergerak sesuai jalur dan wilayah jelajah yang sama, sehingga penyebaran individu macan tutul di HLC cenderung tetap dan tidak akan keluar dari wilayah jelajahnya. Seperti halnya harimau (Panthera tigris), macan tutul biasanya hidup menyendiri (soliter), kecuali pada musim kawin dan masa mengasuh anak (Hoogerwerf, 1970).

Menurut Grzimek (1975) macan tutul tidak akan keluar dari teritorinya jika makanan cukup tersedia dan mudah didapat. Daerah jelajah atau homerange macan tutul secara umum akan terpusat di sekitar sumber mata air dimana mangsa berada di sekitarnya. Daerah jelajah macan tutul antara jantan dan betina juga akan berbeda, jantan memiliki daerah jelajah yang lebih besar dari pada betina. Hal ini dikarenakan jantan akan memangsa mangsa yang lebih besar daripada mangsa macan tutul betina. Ukuran daerah jelajah macan tutul sangat bervarasi 
dan sangat tergantung pada ketersediaan jumlah dan penyebaran satwa mangsa (IUCN, 2008).

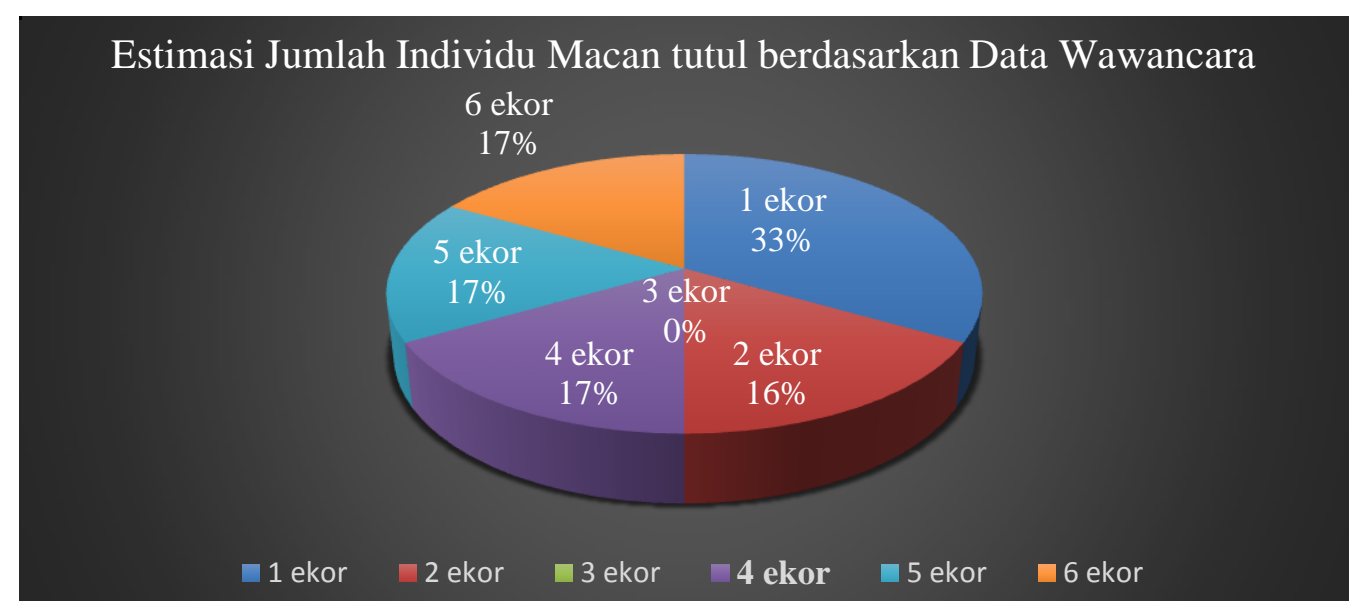

Sumber : Data hasil wawancara (2016)

Gambar 5. Estimasi jumlah individu macan tutul berdasarkan data wawancara

Lokasi jejak macan tutul ditemukan pada 6 lokasi (Blok) yang berbeda di HLC. Lokasi tersebut adalah Blok Legok Honje, Pasir Panjang, Gunung Putri, Gunung Sanggara, Bewak, dan Pangauban. Penyebaran macan tutul di HLC dapat dilihat berdasarkan ciri jejak yang ditinggalkannya (Gambar 8). Pengamatan lapangan menunjukan bahwa jejak yang ditemukan antara lain jejak kaki, bekas cakaran, kotoran dan suara. Jejak tersebut merupakan salah satu cara yang dilakukan oleh macan tutul dalam menandai batas teritorinya. Batas teritori secara teratur ditandai dengan urin, kotoran (feces), kemunculan, cakaran atau garukan di tanah dan pohon. 


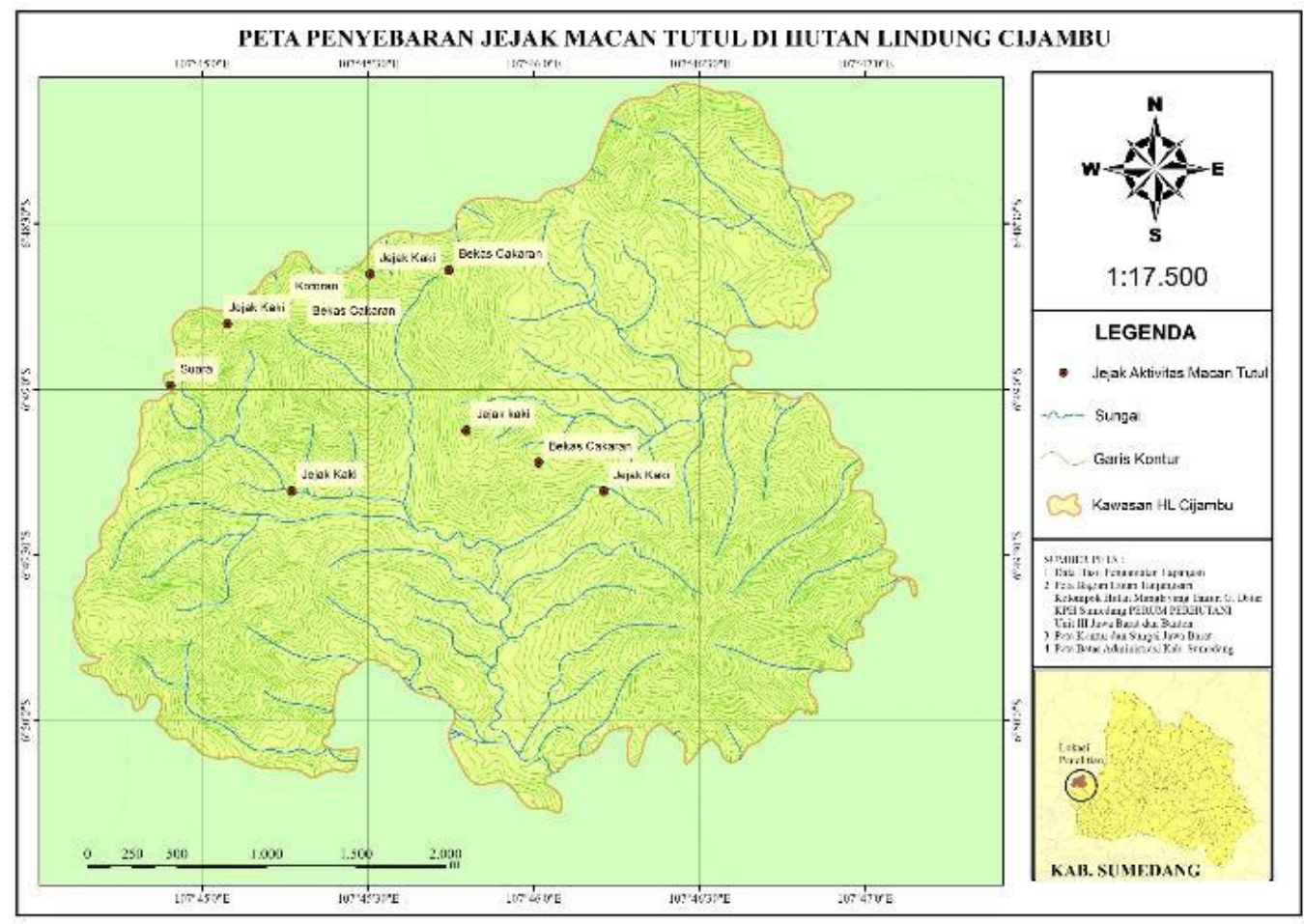

Gambar 6. Peta penyebaran jejak macan tutul (Panthera pardus melas Curvier, 1809) di HLC

Kotoran macan tutul yang di lapangan ditemukan pada jalur lintasan terbuka dan memiliki ciri yang dapat diidentifikasi. Hal ini sesuai dengan hasil beberapa penelitian bahwa macan tutul membuang kotoran di tempat-tempat terbuka seperti di atas batu-batu besar (Gunawan, 2010). Kotoran yang ditemukan memiliki ukuran yang relatif besar dengan panjang $17 \mathrm{~cm}$ dan lebar $11 \mathrm{~cm}$ (Gambar 7). Ukuran tersebut merupakan kotoran yang dihasilkan oleh golongan kucing besar (Panthera). Kemudian kotoran tersebut memiliki ciri khas, yaitu terdapat material pakan yang masih belum hancur yaitu adanya rambut dari mangsa yang dimakan. Pada umunya tidak hanya rambut yang ada pada material kotoran macan tutul, kuku dan tulang juga dapat ditemukan pada kotorannya. 


\section{Kotoran Macan Tutul}

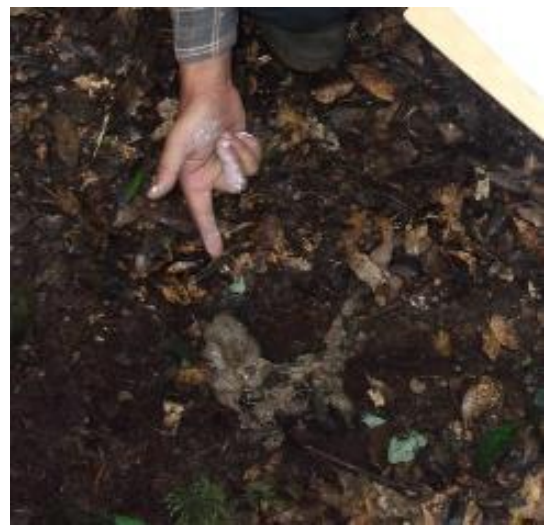

Jejak kaki

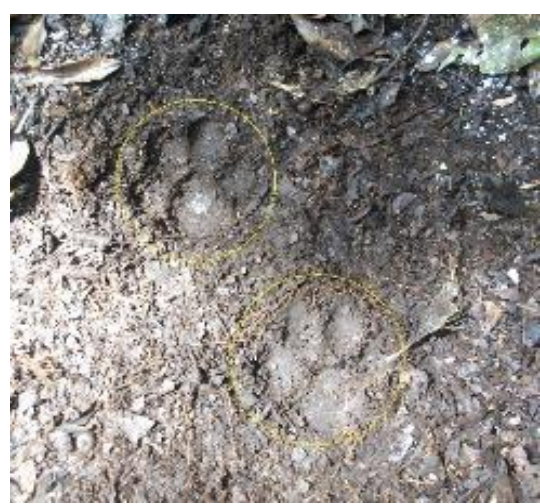

Sumber : Data hasil pengamatan lapangan (2016)

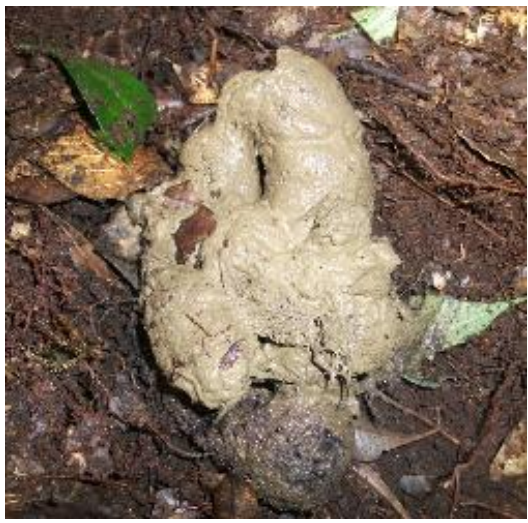

Bekas cakaran ditanah

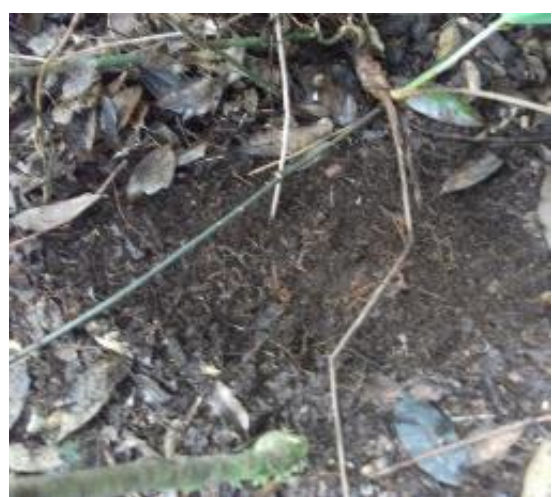

Gambar 7. Dokumentasi jejak macan tutul di HLC

Jejak macan tutul lainnya yaitu suara. Suara yang dikeluarkan macan tutul merupakan salah satu bentuk komunikasi kepada individu lain. Karakteristik suaranya paling banyak adalah suara geraman dan panggilan serak yang mirip dengan suara gergaji mesin (chainsaw). Panggilan serak biasanya dikeluarkan oleh macan tutul jantan untuk mengumumkan teritorinya yang akan dibalas oleh macan tutul lainnya. Suara ini juga dikeluarkan jika ada individu lain disekitarnya, macan tutul akan terus berulang - ulang mengeluarkan suara tersebut sampai individu lain itu pergi (Gunawan, 2010).

Suara yang ditemukan di lapangan terdengar jelas pada malam hari mulai dari pukul 20.00 WIB dan terus berulang sampai dengan pukul 04.00 WIB. Suara tersebut termasuk panggilan serak yang dikeluarkan oleh macan tutul sambil bergerak sesuai dengan wilayah jelajahnya. Suara tersebut berbunyi "eoookk...eoookk", rata - rata dua kali bunyi dalam satu kali suara. Jarak antara suara yang dikeluarkan adalah sekitar 10 - 20 detik. 
Data wawancara yang diperoleh menyebutkan bahwa ciri keberadaan jejak macan tutul tersebar di Blok Legok Honje, Pasir panjang, Pasir Julang, Gunung Putri, Gunung Sanggara, Bewak, dan Pangauban. Lokasi tersebut sesuai dengan data lapangan yang didapatkan, hanya pada Blok Pasir Julang saja yang tidak ditemukan jejak pada saat pengamatan lapangan. Persentase mengenai informasi tersebut disajikan pada Gambar 8.

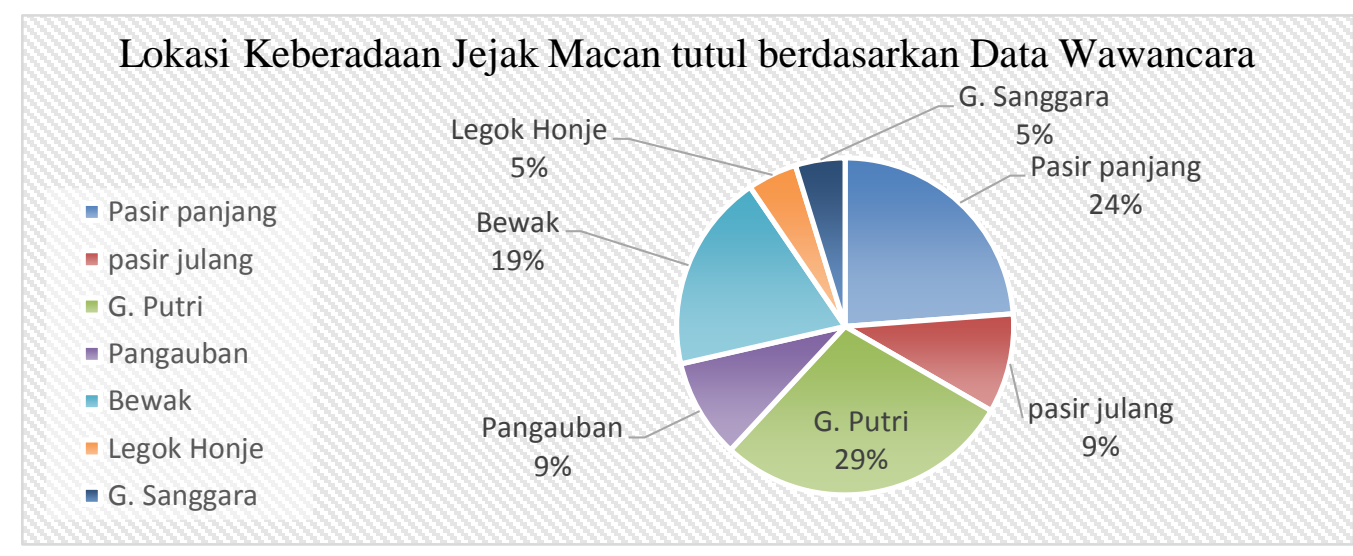

Sumber : Data hasil wawancara (2016)

Gambar 8. Lokasi keberadaan jejak macan tutul berdasarkan data wawancara

\section{Habitat Macan Tutul di Hutan Lindung Cijambu \\ Letak, Luas dan Tipe Hutan}

HLC berada di Desa Cijambu, Kecamatan Tanjungsari, Kabupaten Sumedang. Hutan Lindung Cijambu berada dikawasan hutan yang dikelola oleh Perum Perhutani Divisi Regional Jawa Barat dan Banten, Kesatuan Pemangkuan Hutan (KPH) Sumedang, Bagian Kesatuan Pemangkuan Hutan (BKPH) Manglayang Timur, Resort Pemangkuan Hutan (RPH) Cijambu.

Letak HLC termasuk kedalam wilayah pengelolaan RPH Cijambu. Luas RPH Cijambu adalah 1744,08 Ha, yang terdiri dari 1.129,50 Ha kawasan Hutan Alam Kayu Lain (Hutan Lindung) dan 614,58 Ha kawasan produksi Hasil Hutan Bukan Kayu (Hutan Produksi). Batas wilayah kerja RPH Cijambu, sebelah barat berbatasan dengan RPH Genteng, sebelah utara dengan KPH Purwakarta, sebelah timur dengan RPH Rancakalong, dan sebelah selatan dengan tanah milik masyarakat Desa Cijambu dan Desa Sukasari.

\section{Kondisi Biofisik}

a. Curah Hujan

Menurut Studio proses perencanaan (2013), Intensitas hujan di wilayah Desa Cijambu berkisar 2,77 - 3,48 mm/hari tergolong kedalam klasifikasi tinggi dan lebih dari $3,48 \mathrm{~mm} /$ hari tergolong kedalam klasifikasi sangat tinggi. Dari 
aspek topografi dan iklim, macan tutul memiliki toleransi tinggi terhadap variasi kelerengan, temperatur, dan curah hujan (Ramesh dkk., 2009). Berdasarkan pernyataan tersebut maka HLC memiliki kemungkinan menjadi habitat macan tutul.

b. Ketinggian

Macan tutul lebih menyukai hidup diketinggian lebih dari $1.000 \mathrm{~m} \mathrm{dpl}$, terbukti dengan indeks seleksi tertinggi $(\mathrm{w}=1,80)$, dibandingkan dengan daerah berketinggian $<500 \mathrm{~m}$ dpl yang memiliki indeks seleksi rendah $(\mathrm{w}=0,77)$ (Gunawan, 2010). Jika kita bandingkan dengan kawasan HLC, kawasan ini berada pada ketinggian 1.000 hingga $1.716 \mathrm{~m}$ dpl. Ini membuktikan bahwa macan tutul dapat hidup di HLC karena kondisi ketinggian yang mendukung.

c. Topografi

Topografi yang ada di wilayah HLC memiliki kemiringan lahan bermacammacam, diklasifikasikan dan tergolong landai, agak curam, curam, dan sangat curam. Informasi tersebut disajikan dalam tabel berikut :

Tabel 2. Topografi kawasan HLC

\begin{tabular}{cccc}
\hline No & Klasifikasi & Kemiringan & Luas \\
\hline 1 & Landai & $8 \%-15 \%$ & $28,91 \mathrm{Ha}$ \\
2 & Agak Curam & $15 \%-25 \%$ & $80,02 \mathrm{Ha}$ \\
3 & Curam & $25 \%-40 \%$ & $58,57 \mathrm{Ha}$ \\
4 & Sangat Curam & $>40 \%$ & $33,4 \mathrm{Ha}$ \\
\hline
\end{tabular}

Sumber: Studio proses perencanaan (2013)

Jika dilihat dari topografi kawasan, HLC mendukung untuk habitat macan tutul karena terdapat 33,4 Ha kawasan yang kemiringannya lebih dari 40\%. Itu karena menurut Chundawat (1990), salah satu karakteristik habitat yang disukai macan tutul adalah topografi yang curam dengan lereng - lereng yang lebih dari $40 \%$ dan patahan tebing. Sementara dataran yang dihuni macan tutul umumnya merupakan dataran di puncak atau punggung bukit yang dekat dengan patahan tebing. Selain dari kawasan tersebut, di HLC juga terdapat kawasan dengan kemiringan landai, agak curam, dan curam yang dapat digunakan oleh macan tutul sebagai areal home range nya.

\section{Komponen Habitat Macan Tutul}

Macan tutul dapat bertahan hidup karena ada beberapa faktor pendukung yaitu pakan (satwa mangsa), pelindung (cover) dalam hal ini adalah tegakan pohon, dan air yang tersedia di sungai. Macan tutul hidup pada berbagai habitat. 
Hal ini seperti dengan Gunawan et al. (2012) bahwa macan tutul dapat hidup di habitat dengan hutan tanaman sejenis, hutan tanaman campuran, dan hutan alam, baik dataran rendah maupun pegunungan.

\section{a. Pakan / Satwa mangsa}

Pakan macan tutul yang ada di HLC berdasarkan pengamatan lapangan antara lain ayam hutan (Gallus varius), burung tikukur (Streptopelia chinensis), lutung (Trachypithecus auratus), kijang (Muntiacus muntjak), dan monyet ekor panjang (Macaca fascicularis). Satwa tersebut ditemukan di Blok Gunung Cijambu, Gunung Sanggara, dan Legok Honje. Lokasi tersebut jika diproyeksikan dengan lokasi penyebaran jejak macan tutul maka akan terlihat bahwa satwa mangsa berada pada wilayah sekitar penyebaran macan tutul. Hal ini membuktikan bahwa satwa - satwa tersebut berpotensi sebagai makanan macan tutul dan menjadi penyeimbang ekosistem di HLC.

Direktorat PPA (1978) menyatakan bahwa mangsa macan tutul di Pulau Jawa diantaranya adalah babi hutan, kijang, rusa, monyet, landak, lutung dan burung. Sedangkan Grzimek (1975) berpendapat bahwa satwa-satwa kecil seperti kelinci, binatang pengerat, ikan dan burung juga dimangsa macan tutul, bahkan juga buah - buahan yang manis.

Menurut Noviana (2015), Fauna yang terdapat di HLC antara lain mamalia, reptil, aves dan serangga. Fauna tersebut diantaranya macan tutul (Panthera pardus melas Curvier, 1809), babi hutan (Sus verrucosus), monyet ekor panjang (Macaca fascicularis), lutung (Trachypithecus auratus), kijang (Muntiacus muntjak), bajing (Callosciurus notatus), musang (Paradoxurus hermaphroditus), jenis ular, elang (Spilornis cheela), dan burung julang (Acerossp).

\section{b. Pelindung (cover)}

Pelindung yang biasa digunakan oleh macan tutul sebagai tempat tinggal diantaranya adalah pohon, batu - batu , dan goa. Macan tutul sangat tergantung pada tegakan pohon karena macan tutul adalah satwa arboreal yang berarti mereka makan, tidur, kawin dan memburu mangsanya dari atas pohon (Alderton dalam Gunawan, 2010). Di HLC banyak vegetasi pohon berpotensi sebagai pelindung bagi macan tutul. Tegakan pohon yang mendominasi di HLC antara lain nangsi (Villebrunea rubescens), kihiur (Castanopsis acuminatissima), puspa (Schima walichii), saninten (Castanopsis argentea), kayu pasang (Quercus sundaica), kijambe (Areca catechu), dan beunying (Ficus fistulosa). Tegakan pohon tersebut tersebar di wilayah Blok Legok Honje, Pasir Panjang, Gunung Putri, Gunung Sanggara, Bewak, dan Pangauban.

Tegakan pohon atau vegetasi di HLC menurut Noviana (2015) antara lain : saninten (Castanopsis argentea), puspa (Schima walichii), kisireum (Syzigium 
corymbifera), mindi (Mellia azadarach), bingbin (Pinanga coronate), kitamiang (Trema amboinensis), huru sereh (Laura diversifolia), kileho (Saurauia bracteosa), nangsi (Villebrunea rubescens), kihujan (Samanea saman), kijambe (Areca catechu), lemo (Litsea cubeba), dan jamuju (Dacrycarpus imbricatus).

c. Air

Air adalah salah satu hal yang dibutuhkan oleh semua satwa liar khususnya macan tutul. Macan tutul biasanya mencari air untuk minum setelah makan. Air di HLC cukup mudah ditemukan, hampir disetiap lembahan terdapat mata air yang mengalir. Informasi keberadaan sungai yang ada di HLC dilihat pada Gambar 10. Gambar tersebut merupakan peta yang didalamnya tersedia informasi sungai yang tersedia di kawasan HLC.

\section{KESIMPULAN}

1. Jejak keberadaan macan tutul berupa jejak kaki, kotoran, bekas cakaran, dan suara terdapat di Hutan Lindung Cijambu. Diduga terdapat 3 individu macan tutul yang ditemukan di Hutan Lindung Cijambu

2. Penyebaran jejak macan tutul di Hutan Lindung Cijambu yang ditandai oleh jejak yang ditinggalkan tersebar di Blok Legok Honje, Pasir Panjang, Gunung Putri, Gunung Sanggara, Bewak, dan Pangauban.

\section{DAFTAR PUSATAKA}

Ario, A. 2010. Kucing - Kucing Liar Indonesia. Panduan Lapangan. Yayasan Obor Indonesia. Hal 49 - 55.

Cat Specialist Group. 2002. Panthera pardus. In 2006 IUCN Red List of Threatened Species. IUCN 2006. Diakses Agustus 2016.

CITES. 2016. Convention on International Trade in Endangered Species of Wild Fauna and Flora. Appendices I, II and III. Hal.8.

Direktorat PPA. 1978. Mamalia di Indonesia. Direktorat PPA, Direktorat Jenderal Kehutanan. Bogor.

Grzimek, B. 1975. Animal life encyclopedia Vol. 12, Mammal III. London, England: Van Nostrand Reinhold Company.

Gunawan, H., Lilik, B.P., Ani, M., dan Agus, P.K. 2012. Sebaran Populasi dan Seleksi Habitat Macan Tutul Jawa, Panthera pardus melas Cuvier 1809 di 
Provinsi Jawa Tengah. Jurnal Penelitian Hutan dan Konservasi Alam. Vol. 9 (4): 323-339.

Gunawan, H. 2010. Habitat dan Penyebaran Macan Tutul Jawa (Panthera pardus melas Cuvier, 1809) di Lansekap Terfragmentasi di Jawa Tengah (Disertasi). Institut Pertanian Bogor.

Gunawan, H., Lilik, B.P., Ani, M., dan Agus, P.K. 2009. Habitat Macan Tutul Jawa (Panthera pardus melas Cuvier 1809) di Lanskap Hutan Produksi yang Terfragmentasi. Jurnal Penelitian Hutan dan Konservasi Alam. Vol.VI (2): $95-114$.

Gunawan, H. 1998. Studi Karakteristik Habitat dan Daerah Penyebaran Macan Tutul (Panthera pardus melas Cuvier, 1809) di Jawa Tengah dan Yogyakarta. Jurusan Konservasi Sumberdaya Hutan, Fakultas Kehutanan, Institut Pertanian Bogor. Skripsi S1, Tidak dipublikasikan.

Hoogerwerf, A. 1970. Ujung Kulon, The Land of The Last Javan Rhinoceros. E.J. Brill. Leiden. Netherlands.

Indriyanto. 2005. Ekologi Hutan. Bumi Aksara Group. Bandar Lampung.

IUCN. 2008. The IUCN Red List of Threatened Species. Version 3.1. Panthera pardus. http://www.iucnredlist.org/details/15954/0. Diakses pada 9 September 2016.

IUCN. 2008. The IUCN Redlist of Threatened Species. Version 3.1. Panthera tigris ssp. Sondaica. http://www.iucnredlist.org/details/41681/0. Diakses Tanggal 8 September 2016.

Kurniawan, A. 2009. Studi Keberadaan dan Penyebaran Macan Tutul (Panthera pardus) di Kawasan Cagar Alam Kamojang Kabupaten Garut (Skripsi). Universitas Winaya Mukti.

Noviana, N. 2015. Pola Penyebaran Individu dalam Populasi Jamuju (Dacrycarpus imbricatus) di Hutan Lindung Cijambu Kabupaten Sumedang (Skripsi). Universitas Winaya Mukti.

Peraturan Pemerintah Republik Indonesia Nomor 7 Tahun 1999, Tanggal 27 Januari 1999 tentang Pengawetan Jenis Tumbuhan dan Satwa.

Santoso,Y., A.P. Kartono, D.A. Rahman, dan C. Wulan. 2014. Panduan Inventarisasi Satwa Liar. Direktorat Konservasi Keanekaragaman Hayati Kementrian Kehutanan. Jakarta

Studio Proses Perencanaan. 2013. Identifikasi Potensi dan Masalah Kecamatan Tanjungsari Kabupaten Sumedang.Universitas Pasundan. Bandung.

Sugiyono. 2008. Metode Penelitian Kuantitatif, Kualitatif dan R\&D. Bandung : Penerbit Alfabeta. 